\title{
Compensation, Career Development, and Job Satisfaction as the Antecedent of Nurse Turnover Intention
}

\author{
Nur Hidayah ${ }^{1}$, Hana Rizki Ananda ${ }^{2}$ \\ ${ }^{*}$ Ccorrespondence Author: murhidayah@umy.ac.id \\ ${ }^{1}$ Master of Hospital Administration. Universitas Muhammadiyah Yogyakarta. Yogyakarta, Indonesia \\ 2Berangas Nursing Health Center, South Kalimantan, Indonesia
}

\section{N D E X I N G}

Keywords:

Compensation;

Career;

Satisfaction;

Nurse Turnover;

Intention

Kata kunci:

Kompensasi;

Karir;

Kepuasan;

Pergantian Perawat

\begin{abstract}
A B S T R AC T
The shortage of professional nurses in a hospital is to threaten service quality and patient safety. Inadequate compensation, no career development, and dissatisfaction can increase turnover intention. Increasing professional nurses' resilience is better than recruiting new nurses from an economic perspective. The research analyzed the effect of compensation and carrier development on job satisfaction and the impact on nurses' turnover intention in a private hospital in Yogyakarta, Indonesia. A quantitative research design with the cross-sectional approach was used. The sampling technique was simple random sampling. The samples consisted of 47 nurses who made a self-reported by filling out the questionnaire. Data analysis used Partial Least Square. The study found that compensation and career development had direct and significant effects on Turnover Intention. Moreover, compensation and career development also had indirect and significant Turnover Intention effects through job satisfaction as the intervening variable.
\end{abstract}

Kekurangan tenaga perawat profesional di rumah sakit mengancam kualitas pelayanan dan keselamatan pasien. Kompensasi yang tidak memadai, tidak ada pengembangan karir, dan ketidakpuasan dapat meningkatkan turnover intention. Meningkatkan ketahanan perawat profesional lebih baik dari pada merekrut perawat baru dari segi ekonomi. Penelitian ini menganalisis pengaruh kompensasi dan pengembangan karir terhadap kepuasan kerja dan dampak turnover intention perawat di rumah sakit swasta di Yogyakarta, Indonesia. Desain penelitian kuantitatif dengan pendekatan cross-sectional digunakan. Teknik pengambilan sampel adalah simple random sampling. Sampel terdiri dari 47 perawat yang membuat laporan sendiri dengan mengisi kuesioner. Analisis data menggunakan Partial Least Square. Penelitian ini menemukan bahwa kompensasi dan pengembangan karir berpengaruh langsung dan signifikan terhadap Turnover Intention. Selain itu, kompensasi dan pengembangan karir juga berpengaruh tidak langsung dan signifikan terhadap Turnover Intention melalui kepuasan kerja sebagai variabel intervening.

C) 2021 JMMR. All rights reserved

Article history: Received 2020-12-18; Revised 2021-02-15; Accepted 2021-06-11

\section{INTRODUCTION}

One of the worldwide issues is the shortage of nurses (Khatijah et al., 2018). The shortage of professional nurses in a hospital is threatened by service quality and patient safety. The shortage impacts hospital operations, especially on access and quality. It is because nursing plays an essential element in providing quality and effective health service (Aboshaiqah, 2016; Lu et al., 2017). Severe shortages increase nurse workloads or overtime, affecting the quality of healthcare (Khatijah et al., 2018; May et al., 2006). Intention to change profession and intention to change, proper staffing, and a stable nursing workforce will ensure the quality of nursing care received by patients and their quality. Thus, having a sufficient number of nurses is essential-turnover that related to the nurse shortage (Parry, 2008). Thus, nurse turnover becomes one of the global reasons for a nurse (Feng et al., 2017).

In light of the workforce shortage protected, turnover is a crucial issue in the world. Turnovers strongly correlate with patient outcomes, exceptionally patient safety (falls, 
infections), low job satisfaction, and quality of patient care (Lu et al., 2017; Roche et al., 2015). Job satisfaction affects turnover intention (Arianto \& ., 2018; Khatijah et al., 2018; Lu et al., 2017; Oktizulvia et al., 2017). The previous research in West Sumatera Indonesia found that potential half of nurses (51.9\%) intended to quit (turn over) next year. The average job satisfaction was $48.6 \%$ (Arianto \& ., 2018). Besides, turnover intention also correlates with financial rewards. The management should pay attention to financial rewards to reduce turnover intention (Olawale \& Olanrewaju, 2016). Financial reward and career development can influence turnover intention (Ghafoor et al., 2017; Khatijah et al., 2018). Reward and compensation have similar meanings that are appreciation from employer to employee. There is a value exchange between them. The organization gives financial rewards or compensation to the workers because of their contribution (Salisu et al., 2015).

Career development is essential for every nurse professional to maintain the nurse competencies needed to continue career development. A study found that continuing professional development positively correlated with nurse satisfaction (Hariyati et al., 2017). The other study also showed that providing workforce development opportunities became an essential tool in improving nurse satisfaction (Duffield et al., 2014). Therefore, by providing career development, it can also support the hospital in providing high-quality services and in achieving the best hospital performance (Trivellas et al., 2013).

Inadequate compensation, unclear career development, and dissatisfaction can increase turnover intention (Hinno et al., 2011). Increasing the resilience of professional nurses is better than recruiting new nurses from an economic perspective. The cost of turnover is high. Employees are essential assets and the building blocks of an organization (Kumar \& Khan, 2013), especially in healthcare organization. Researchers and practitioners stated that an organization should satisfy and retain critical performers or lose much money to train and develop a new employee (Abid \& Hassan Butt, 2017). So, raising the turnover of the workforce becomes a severe organizational problem.

Many researchers have done a study on the correlation between job satisfaction and intention turnover. Current research investigates the causal effect of financial compensation, and career development on turnover intention, job satisfaction as variable intervening. This research also measures the contribution of indicators on a research variable in detail.

\section{Hypothesis $(\mathrm{H})$}

H1: $\quad$ Financial compensation effect on job satisfaction

H2: $\quad$ Financial compensation effect on turnover intention

H3: Career development effect on job satisfaction

H4: Career development effect on turnover intention

H5: Job satisfaction effect on turnover intention.

\section{RESEARCH METHOD}

This study used a quantitative research design. Structure Equation Modeling (SEM) alternative, namely Partial Least Square (PLS), became the data analysis tool. The crosssectional survey was used as a self-administered questionnaire. The sampling technic was a sample random sample with the Slovin method. Samples were 47 nurses, from a total of 90 nurses. The inclusion criteria were the nurse who has been working for two years or more. 
The study was performed from April 2016 to June 2016 in a private hospital in Yogyakarta, Indonesia.

\section{Result}

\section{RESULT AND DISCUSSION}

\section{Respondent Characteristic}

Respondents' characteristic presents personal information of the respondents. There are five categories based on respondents' characteristic namely gender, ages, education, marital status, and employment status. Also, each category followed by frequency and percentage. The table of respondents' characteristic is shown below.

Table.1 Respondents' Characteristics

\begin{tabular}{|c|c|c|}
\hline Category & Frequency & Percentage \\
\hline Men & 5 & 10.6 \\
\hline Women & 42 & 89.4 \\
\hline$<25$ Years & 4 & 8.5 \\
\hline 25-30 Years & 23 & 48.9 \\
\hline 31-35 Years & 8 & 17.0 \\
\hline$>35$ Years & 12 & 25.5 \\
\hline D3 & 33 & 70.2 \\
\hline S1 & 14 & 29.8 \\
\hline Single & 11 & 23.4 \\
\hline Married & 36 & 76.6 \\
\hline Contract & 8 & 17.0 \\
\hline Permanent & 39 & 83.0 \\
\hline
\end{tabular}

\section{Outer Model}

Outer model shows the convergent validity consisting of individual item reliability, internal consistency or Constructs Reliability (CR), and Average Variance Extracted (AVE). Convergent validity measures the correlation between the construct and the latent variable. Thus, the outer model is presented in the following table of Cronbach's Alpha, Construct Reliability (CR), and Average Variance Extracted (AVE).

Table.2 Cronbach's Alpha, Construct Reliability (CR), and Average Variance Extracted (AVE)

\begin{tabular}{lccc}
\hline & Cronbach's Alpha & CR & AVE \\
\hline Career Development & 0,997 & 0,998 & 0,978 \\
\hline Financial Compensation & 0,977 & 0,982 & 0,917 \\
\hline Job Satisfaction & 1,000 & 1,000 & 0,993 \\
\hline Turnover Intention & 0,864 & 0,918 & 0,791 \\
\hline
\end{tabular}

Besides that, there is also discriminant validity. If the loading factor is $\leq 0.7$, it is ideal, and the indicator is valid. There are five financial compensation indicators, nine career development indicators, 19 indicators of job satisfaction, all of them are valid $(\geq 0.7)$. There are eight indicators of turnover intention, but the first (y21), second (y22), third (y23), fourth (y24), and fifth indicator (y25) has a loading factor of $\leq 0.7$, so they are not valid and have to 
be a drop from the model, as follows. Additionally, discriminant validity is presented by following tables namely table Table.3 Outer Loading of Financial Compensation (FC), Table.4 Outer Loading of Career Development (CD), Table.5 Outer Loading Job Satisfaction (JS), and Table.6 Outer Loading of Turnover Intention (TI).

Table.3 Outer Loading of Financial Compensation (FC)

\begin{tabular}{llll}
\hline & Original Sample & T Statistics & P Values \\
\hline $\mathrm{X} 11<-\mathrm{FC}$ & 0,923 & 19,642 & 0,000 \\
\hline $\mathrm{X} 12<-\mathrm{FC}$ & 0,964 & 12,972 & 0,000 \\
\hline $\mathrm{X} 13<-\mathrm{FC}$ & 0,964 & 13,080 & 0,000 \\
\hline $\mathrm{X} 14<-\mathrm{FC}$ & 0,966 & 10,916 & 0,000 \\
\hline $\mathrm{X} 15<-\mathrm{FC}$ & 0,968 & 15,148 & 0,000 \\
\hline
\end{tabular}

Table.4 Outer Loading of Career Development (CD)

\begin{tabular}{llll}
\hline & Original Sample & T Statistics & P Values \\
\hline X21 <-CD & 0,977 & 15,394 & 0,000 \\
\hline X22 <-CD & 0,983 & 10,319 & 0,000 \\
\hline X23 <-CD & 0,989 & 9,750 & 0,000 \\
\hline X24<-CD & 0,988 & 8,872 & 0,000 \\
\hline X25 - CD & 0,994 & 15,790 & 0,000 \\
\hline X26 <-CD & 0,993 & 11,331 & 0,000 \\
\hline X27 <- CD & 0,992 & 11,386 & 0,000 \\
\hline X29 - CD & 0,992 & 11,424 & 0,000 \\
\hline
\end{tabular}

Table.5 Outer Loading Job Satisfaction (JS)

\begin{tabular}{|c|c|c|c|}
\hline & Original Sample & T Statistics & P Values \\
\hline Y11< JS & 0,995 & 4,122 & 0,000 \\
\hline $\mathrm{Y} 110<\mathrm{JS}$ & 0,998 & 5,316 & 0,000 \\
\hline Y111<- JS & 0,996 & 4,456 & 0,000 \\
\hline Y112<- JS & 0,998 & 4,404 & 0,000 \\
\hline Y113<-JS & 0,998 & 4,457 & 0,000 \\
\hline Y114<- JS & 0,997 & 5,332 & 0,000 \\
\hline Y115<JS & 0,998 & 5,393 & 0,000 \\
\hline Y116<- JS & 0,998 & 3,407 & 0,001 \\
\hline Y117<- JS & 0,997 & 2,771 & 0,006 \\
\hline Y118<- JS & 0,996 & 2,671 & 0,008 \\
\hline Y12<-JS & 0,992 & 4,625 & 0,000 \\
\hline Y13<-JS & 0,996 & 5,016 & 0,000 \\
\hline Y14<-JS & 0,995 & 3,837 & 0,000 \\
\hline Y15<-JS & 0,995 & 5,113 & 0,000 \\
\hline Y16<-JS & 0,996 & 5,790 & 0,000 \\
\hline Y17 <-JS & 0,996 & 5,604 & 0,000 \\
\hline Y18<-JS & 0,996 & 4,354 & 0,000 \\
\hline Y19<-JS & 0,997 & 4,849 & 0,000 \\
\hline
\end{tabular}


Table.6 Outer Loading of Turnover Intention (TI)

\begin{tabular}{llll}
\hline & Original Sample & T Statistics & P Values \\
\hline Y26<- TI & 0,765 & 6,161 & 0,000 \\
\hline Y27 < TI & 0,942 & 23,027 & 0,000 \\
\hline Y28<-TI & 0,949 & 19,543 & 0,000 \\
\hline
\end{tabular}

\section{Inner Model}

In the inner model, show the path coefficients, effect exogenous variable on the endogenous variable. There are two exogenous variables (financial compensation and career development) and two endogenous variables (job satisfaction and turnover intention).

\section{Result of Hypothesis Testing:}

According to Table 7, original samples are the path coefficients. The significance level of the path coefficients can be seen on T Statistic and $\mathrm{P}$ values. If T Statistics $>1,96(\mathrm{t}-$ distribution table) or p-value $>0,05$ for $5 \%$ significance level, then the path coefficient is significant. Additionally, there are four abbreviations of causal effect namely FC: Financial Compensation; CD: Career Development; JI: Job satisfaction; TI: Turnover Intention

Table.7 Path Coefficients

\begin{tabular}{llll}
\hline Causal Effect & Original Sample & T Statistic & P Values \\
\hline CD $>$ JS & 1,127 & 2,538 & 0,011 \\
\hline CD $>$ TI & $-1,431$ & 2,011 & 0,045 \\
\hline FC $>$ JS & $-0,157$ & 0,686 & 0,493 \\
\hline FC $>$ TI & $-0,317$ & 1,628 & 0,104 \\
\hline JS $>$ TI & 2,454 & 2,256 & 0,024 \\
\hline
\end{tabular}

\section{The Result of Hypothesis Testing}

H1: Financial compensation effect on job satisfaction; The coefficient is $-0,158$ (pvalue 0.443$)$. The minus coefficient does not support the theory. Financial compensations should have a positive effect on job satisfaction. The p-value also shows the effect is not significant. So, H1: financial compensation affecting job satisfaction is not proven. H2: Financial compensation effect on turnover intention; The coefficient is $-0,470$ ( $\mathrm{p}$-value 0,018). The H2: financial compensation effect turnover intention is proven. The financial compensation significantly affects turnover intention - 4, $7 \%$.

H3: Career development effect on job satisfaction; The coefficient is $1,128(0,010)$. Career development affects job satisfaction 11, 28\%, significantly. H4: Career development effect on turnover intention - 0,952 (p-value 0,080). Career development affects turnover intention 9,52\%, significantly. H5: Job satisfaction effect on turnover intention; The coefficient 2,195 (positive), (p-value 0,005), does not support the theory. Job satisfaction must hurt turn over the intention. So, H5: Job satisfaction effect on turnover intention is not proven.

$\mathrm{R}$ square Job satisfaction is 0,964 . The variation of career development can describe job satisfaction variation, and financial compensation is $96,3 \%$. 
$\mathrm{R}$ square turnover intention is 0.839 . It is described variability turnover intention can be described by the variability of compensation, career development, and job satisfaction 83 , $9 \%$.

\section{Discussion}

The result of the research shows that financial compensation does not affect job satisfaction. This result is not relevant to previous research that compensation positively influenced job satisfaction (Salisu et al., 2015; Sudarno et al., 2016). One of the goals of giving financial compensation is to motivate the employee and to satisfy them. So, the organization should evaluate the financial compensation to improve job satisfaction.

There are so many factors that affect satisfaction. Research by Lu et al. on the 5845healthcare staff in Guangdong found that the job satisfaction score mean was 3.99 on the scale of 1-6. Job satisfaction was affected significantly by educational background, professional status, occupation, night shift frequency, year of service, and annual income as the socio-demographic variables. Work stress, work-family conflict, and doctor-patient relationship also significantly affected job satisfaction (Lu et al., 2017). Compensation is not only in the form of financial. Non-financial compensation includes included flexible working, opportunities to get training, dress, free food, free for the wellness program (Ciaran, 2018), transportation, health insurance, etcetera. In this research, non-financial compensation is more attractive than financial compensation and makes the employee satisfied. It needs another study to prove it.

Compensation strategies that comprehensive include basic or fix salary, bonuses as variable payment, reimbursements, employees allow choosing from a budget as flexible benefits and a pension level based on their contribution, transportation allowance, healthcare service, support for private medical, personal development support, and opportunity to choose additional holidays. The best packages include long-term incentives to contribute value created, such as share options, and these can vary differently from one organization to another organization (Ciaran, 2018).

To attract, retain talented employees, and motivate the best performer, the organization can use an effective compensation strategy. To keep competitive and successful, an organization can use the compensation strategy as a critical part of the overall human resource one. By the strategy, the organization motivates the employee and develops emerging talent. Compensation strategies that are genuinely useful, as same as most other business strategies: differentiation, based on market demand, aligned with the needs and goals of the organization; and fit with the lifecycle of what is the employee thinks (Ciaran, 2018).

Compensation and career development significantly affected turnover intention (Ghafoor et al., 2017; Khatijah et al., 2018). Organizations want to minimize the turnover intentions of its employee. Retaining a performed and productive employee is better than recruit and train a new one. In the workplace, employees desire to have self-actualization by getting higher compensation and good career development. As a mediator variable, selfactualization could increase or decrease the effect of compensation and career development on turnover intention (Ghafoor et al., 2017).

A career map of the nurse is a guide for professional development. Nurses have essential roles in enhancing healthcare quality in a hospital. They are responsible for patient 
safety. So, they must have adequate competencies. The hospital should provide programs that continuously improve nurse competencies. The professional development of nurses must be maintained from time to time as a continuous process. Career development is an integral part of a nurse's career ladder (Hariyati et al., 2017).

The sampling method of this study only involved 47 nurse's sample. The reason because 47 nurses' samples are sufficient to answer the gap in this study. Thus, this study was not involved in the managerial sample in the sampling method.

\section{CONCLUSION}

The study showed a lack of work support negatively and directly associated with nurse turnover intention. Additional opportunities for career growth within the organization may strengthen work support and increase qualified nursing staff retention. Therefore, the retention of skilled nurses became a priority to decrease nurse turnover intention.

\section{ACKNOWLEDGMENT}

The authors thank all parties involved in making this research possible.

\section{REFERENCE}

Abid, G., \& Hassan Butt, T. (2017). Expressed Turnover Intention: Alternate Method for Knowing Turnover Intention and Eradicating Common Method Bias. International Letters of Social and Humanistic Sciences, 78, 18-26. https://doi.org/10.18052/www.scipress.com/ILSHS.78.18

Aboshaiqah, A. (2016). Strategies to address the nursing shortage in Saudi Arabia. International Nursing Review, 63(3), 499-506. https://doi.org/10.1111/inr.12271

Arianto, A., \&. S. (2018). The Influence of Reward on Turnover Intention with the Organizational Commitment as an Intervening Variable (A Study on Group I and II Employee at Djatiroto Sugar Factory). KnE Social Sciences, 3(3), 308. https://doi.org/10.18502/kss.v3i3.1891

Ciaran, S. (2018). Compensation Strategies: Attracting and Retaining Talent. https://www.legalisland.com/articles/uk/features/hr/2018/may/compensation-strategies-attractingand-retaining-talent/

Duffield, C., Baldwin, R., Roche, M., \& Wise, S. (2014). Job enrichment: Creating meaningful career development opportunities for nurses. Journal of Nursing Management, 22(6), 697-706. https://doi.org/10.1111/jonm.12049

Feng, D., Su, S., Yang, Y., Xia, J., \& Su, Y. (2017). Job satisfaction mediates subjective social status and turnover intention among Chinese nurses: Turnover intention of Chinese nurses. Nursing $\mathcal{E} \quad$ Health Sciences, 19(3), 388-392. https://doi.org/10.1111/nhs.12357

Ghafoor, M. S., Ansari, D. N., \& Moazzam, D. A. (2017). The Effect of Financial Compensation and Perceived Career Progression on Employee Turnover Intentions with Self Actualization As A Mediator. Management Review, 1(2), 26. 
Hariyati, T. S., Igarashi, K., Fujinami, Y., Susilaningsih, S., \& Prayenti, P. (2017). Correlation between Career Ladder, Continuing Professional Development and Nurse Satisfaction: A Case Study in Indonesia. 10(3), 1490.

Hinno, S., Partanen, P., \& Vehviläinen-Julkunen, K. (2011). Hospital nurses' work environment, quality of care provided and career plans: Nurses' work environment, care quality and career plans. International Nursing Review, 58(2), 255-262. https://doi.org/10.1111/j.1466-7657.2010.00851.x

Khatijah, O., Abdul Majid, A. halim, \& Johari, H. (2018). Job Satisfaction and Turnover Intention Among Nurses: The Mediating Role of Moral Obligation. Journal of Global Management, 5(1), 44-55.

Kumar, P., \& Khan, A. M. (2013). Human Resource Management in Primary Health Care System. Health and Population, 36(1 \& 2), 12.

Lu, Y., Hu, X.-M., Huang, X.-L., Zhuang, X.-D., Guo, P., Feng, L.-F., Hu, W., Chen, L., Zou, H., \& Hao, Y.-T. (2017). The relationship between job satisfaction, work stress, work-family conflict, and turnover intention among physicians in Guangdong, China: A cross-sectional study. BMJ Open, 7(5), e014894. https://doi.org/10.1136/bmjopen-2016-014894

May, J. H., Bazzoli, G. J., \& Gerland, A. M. (2006). Hospitals' Responses to Nurse Staffing Shortages: Hospitals' actions are having a positive impact, but can it be sustained for the long run? Health Affairs, 25(Suppl1), W316-W323. https://doi.org/10.1377/hlthaff.25.w316

Oktizulvia, C., Dachriyanus, D., \& Vionalisa, V. (2017). Job Satisfaction Factors and Nurses Intention to Quit in Type C Hospitals. Journal of Nursing $\mathcal{E}$ Care, 06(03). https://doi.org/10.4172/2167-1168.1000399

Olawale, R., \& Olanrewaju, I. (2016). Investigating The Influence of Financial Reward on Lagos State University Staff Turnover Intention. European Scientific Journal, ESJ, 12(10), 161. https://doi.org/10.19044/esj.2016.v12n10p161

Parry, J. (2008). Intention to leave the profession: Antecedents and role in nurse turnover. Journal of Advanced Nursing, 64(2), 157-167. https://doi.org/10.1111/j.13652648.2008.04771.x

Roche, M. A., Duffield, C. M., Homer, C., Buchan, J., \& Dimitrelis, S. (2015). The rate and cost of nurse turnover in Australia. Collegian, 22(4), 353-358. https://doi.org/10.1016/j.colegn.2014.05.002

Salisu, J. B., Chinyio, E., \& Suresh, S. (2015). The impact of compensation on the job satisfaction of public sector construction workers of jigawa state of Nigeria. 6(4), 15.

Sudarno, S., Priyono, P., \& Sukmaningrum, D. (2016). Effect of Compensation, Motivation and Organizational Climate on Employee Satisfaction: Study on PT. Sumber Alfaria Trijaya Tbk. in Gedangan-Sidoarjo. International Journal of Business and Management, 11(2), 212. https://doi.org/10.5539/ijbm.v11n2p212 
Trivellas, P., Reklitis, P., \& Platis, C. (2013). The Effect of Job-Related Stress on Employees' Satisfaction: A Survey in Health Care. Procedia - Social and Behavioral Sciences, 73, 718726. https://doi.org/10.1016/j.sbspro.2013.02.110 